\title{
The integration of young people into the labour market: the role of training systems and labour market regulation
}

Citation for published version (APA):

van der Velden, R. K. W., \& Wolbers, M. H. J. (2003). The integration of young people into the labour market: the role of training systems and labour market regulation. In W. Müller, \& M. Gangl (Eds.), Transitions from education to work in Europe. The integration of youth into EU labour markets (pp. 186211). Oxford University Press.

Document status and date:

Published: 01/01/2003

Document Version:

Publisher's PDF, also known as Version of record

Please check the document version of this publication:

- A submitted manuscript is the version of the article upon submission and before peer-review. There can be important differences between the submitted version and the official published version of record.

People interested in the research are advised to contact the author for the final version of the publication, or visit the DOI to the publisher's website.

- The final author version and the galley proof are versions of the publication after peer review.

- The final published version features the final layout of the paper including the volume, issue and page numbers.

Link to publication

\footnotetext{
General rights rights.

- You may freely distribute the URL identifying the publication in the public portal. please follow below link for the End User Agreement:

www.umlib.nl/taverne-license

Take down policy

If you believe that this document breaches copyright please contact us at:

repository@maastrichtuniversity.nl

providing details and we will investigate your claim.
}

Copyright and moral rights for the publications made accessible in the public portal are retained by the authors and/or other copyright owners and it is a condition of accessing publications that users recognise and abide by the legal requirements associated with these

- Users may download and print one copy of any publication from the public portal for the purpose of private study or research.

- You may not further distribute the material or use it for any profit-making activity or commercial gain

If the publication is distributed under the terms of Article $25 \mathrm{fa}$ of the Dutch Copyright Act, indicated by the "Taverne" license above, 


\title{
The integration of young people into the labour market: the role of training systems and labour market regulation
}

\author{
ROLF K. W. VAN DER VELDEN AND \\ MaARTEN H. J. Wolbers
}

\subsection{Introduction}

The transition from school to work has been a major research topic over the last ten years (for overviews see Hannan and Werquin 2001 and Ryan 2001). The main reason for this attention is the occurrence of persistently high youth unemployment rates since the 1980s. A considerable number of young people are unemployed in the period after leaving school, and even those who immediately find a job are often working in vulnerable positions. This makes the integration process of young people into the labour market (LM) far from smooth and the transition from school to work can, therefore, be characterized as a turbulent and uncertain period for young people (OECD 1998b: 111). However, there are large differences between countries. In some countries, young people are smoothly integrated into the labour market, while in others young people experience serious and persistent problems. Figure 7.1 presents two important indicators with respect to the LM integration of young people for the various countries of the European Union.

The upper panel of Figure 7.1 shows the average unemployment rate among school leavers. The mean unemployment rate within the European Union is 21 per cent, which indeed points to serious transition problems. In Italy and Spain, around 40 per cent of all school leavers are unemployed. In Greece too, a large proportion of young people entering the labour market are unemployed (30 per cent). In Luxembourg, Austria, the Netherlands, and Germany, on the other hand, less than 10 per cent of all school leavers are without a job. All other countries take up a position somewhere in between. 
(a)
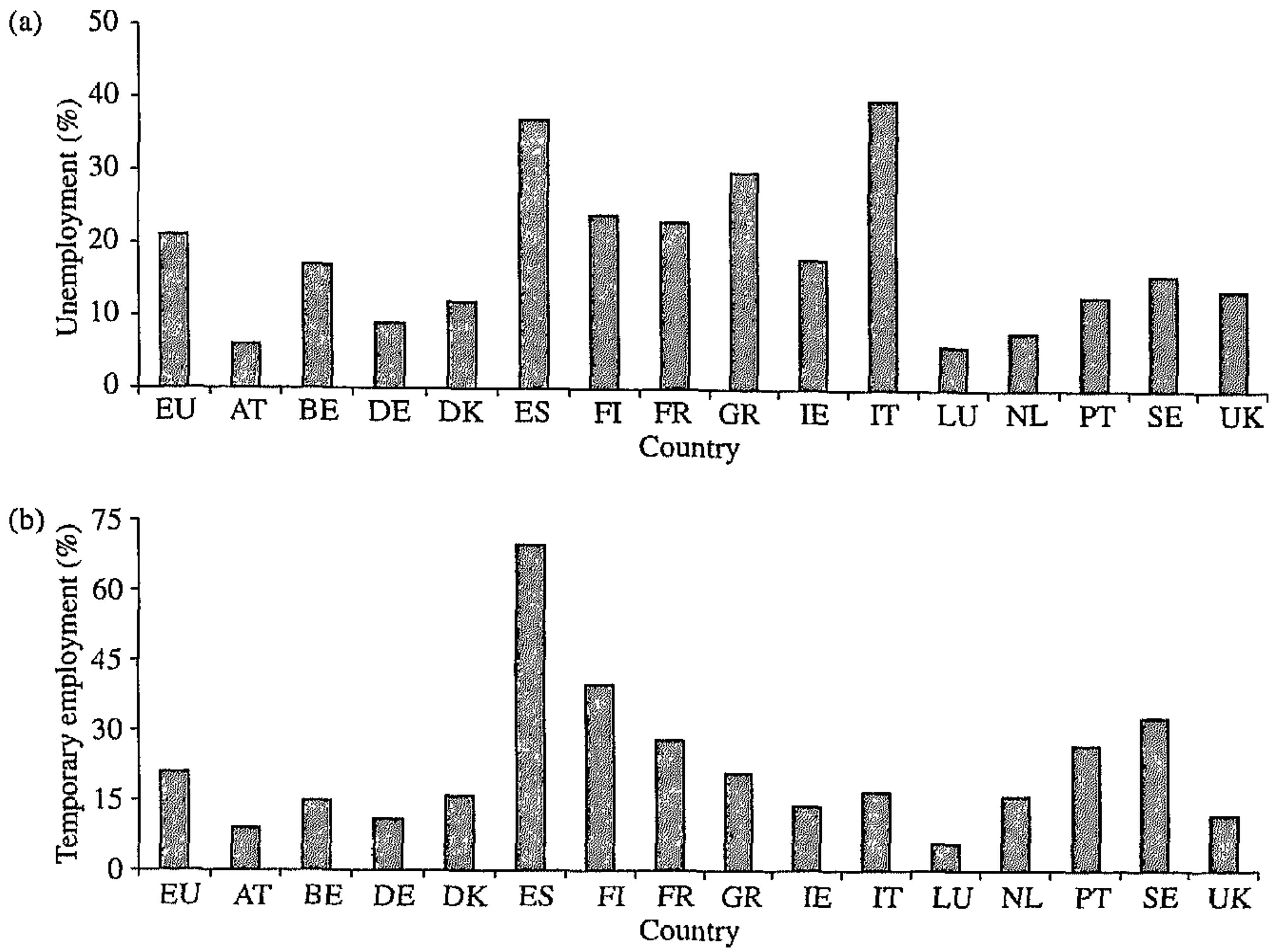

Figure 7.1. (a) Unemployment and (b) temporary employment among school leavers, by country.

Source: Pooled EULFS data 1992-7.

The lower panel of Figure 7.1 displays the proportions of school leavers holding a temporary job. Again, there is considerable variation across the countries of the European Union. Spain certainly has the top-rank position. In this country, almost three-quarters of all workers who have recently entered the labour market have a temporary job. This finding implies that in Spain the integration process of young people is not only hindered by a large number of individuals who are unemployed but even among those who are employed there are many in a precarious LM position, in the sense that their contract is temporary. Finland, Sweden, France, and Portugal also have a relatively large proportion of school leavers with temporary contracts. All other countries show percentages below the EU average. Only in Luxembourg (6 per cent) and Austria ( 9 per cent) do fewer than one-tenth of the employed school leavers have a temporary work contract.

Of course a major factor underlying this cross-national variation in the integration of young people into the labour market is the overall economic situation. As the OECD has pointed out, 'a well functioning economy is perhaps the most fundamental factor to shape young people's transition from initial 
education to work' (OECD 2000b: 13). But there are also other structural constraints that shape the opportunity structure for newcomers in the labour market (Kerckhoff 1995; Ryan 2001). In this chapter, we investigate the way in which national institutional settings affect the integration process of young people into the labour market within the European Union. These institutional settings refer to national institutional contexts with regard to both the education/ training system and the employment system. The aim is to highlight similarities and differences in the integration patterns between the various countries and to relate these to differences in national institutional contexts. For this purpose, multilevel analysis is applied to the data, which enables us to control for structural effects in the integration process with regard both to institutional differences between countries and to changing LM circumstances in terms of business cycle effects.

The remaining part of this chapter is organized as follows. The next section presents the theoretical background, in which a set of hypotheses is formulated about the impact of national institutional arrangements on the integration process of young people into the labour market. In the third section we discuss the research design. The hypotheses formulated here are empirically tested in the Section 7.4. The chapter ends with a concluding section that summarizes and discusses the most important findings.

\subsection{Theoretical background}

\section{Insiders versus outsiders}

The integration of young people into the labour market is largely dependent on the extent to which the labour market absorbs school leavers. The insider-outsider theory appears very promising and interesting in this respect (Lindbeck and Snower 1988). As its name indicates, this theory relies on the distinction between 'insiders' and 'outsiders'. Employed workers are insiders and unemployed workers are, in general, referred to as outsiders. However, a specific group of outsiders consists of LM entrants (de Vreyer et al. 2000), since school leavers without any work experience have to compete for available jobs with those who have already gained a position on the labour market. Accordingly, young people constitute the main group of outsiders.

According to the insider-outsider theory, wage-bargaining takes place between insiders and employers. Outsiders play no role in this process. The main interest of insiders is to stay employed. They set their wage strategically so that their continued employment is assured. The employment of outsiders has no priority. As long as the economic system is not subject to radical changes in social institutions or a major shock (such as an oil crisis or a war), 
insiders bargain so as to get the highest wage level possible without losing their employment. As a consequence, the difficulties outsiders have in obtaining jobs do not change and unemployment remains at the same level.

The level at which wage bargaining takes place determines the strength of the insider-outsider dichotomy and with it the degree of youth LM integration. At one extreme, wage-bargaining is called centralized when employees and employers are organized into nationwide unions, when the rate of unionization of both employers and employees is high, and when wages are negotiated at a central level. At the other extreme, firms and employees can negotiate on wages at the level of the individual enterprise. In that case, the wage-bargaining structure is labelled as decentralized. Lastly, wage-bargaining is called intermediately centralized when wage negotiations occur at industry level.

Calmfors and Driffill (1988) have argued that the unemployment levels of countries-and implicitly the insider-outsider dichotomy-are lowest at both extremes of centralization. Countries characterized by intermediately centralized economies, however, have to deal with larger unemployment rates. This phenomenon is known as the hump-shaped relationship between the degree of centralization and unemployment.

The arguments adduced for this relationship are sought in imperfectly competitive labour markets. Both in decentralized and centralized wagebargaining systems, the agents involved in the bargaining process face a very adverse tradeoff between the real wage and employment, but for different reasons. The tradeoff is adverse for decentralized unions, because if they set a high money wage this will be passed on to the prices asked by the firm. The price increase will lead to a substantial loss of demand for the firm's products and consequently to lower employment. Together, these factors will induce unions that operate in decentralized wage-bargaining systems to make moderate wage demands. In a centralized wage-bargaining structure, on the other hand, high money (nominal) wages set by unions will not lead to equally high real wage increases, because of the collective wage agreements. The collective character of the wage-bargaining structure will lead to high money wages throughout the whole economy and, consequently, to high price changes throughout the whole economy as well. The only effect that setting high money wages will have is a deterioration of the international competitive position and a threat of increasing unemployment. Again, there is no incentive for unions to set high money wages.

The contrary applies to unions operating in intermediately centralized wage-bargaining systems. High wage demands by unions will lead to only a limited loss of demand for the products of the firm, if this firm passes on the wage increases to the product prices, because all firms within the sector have to increase their prices. The other argument that would induce unions to make moderate wage demands--high nominal wage demands will not lead to 
high real wage increases, because of the general price increases-applies only partially, if at all, to the intermediate case. Only those prices within the same sector will rise, not those in other sectors. This will make real wage increases nearly as high as nominal wage increases. Therefore, in intermediately centralized wage-bargaining systems there is indeed an incentive to make high wage demands.

In previous empirical studies, however, there has been little systematic evidence of a hump-shaped relationship between the degree of centralization in the wage-bargaining process and the level of unemployment (OECD 1997b: chapter 3). Instead, some authors (e.g. Soskice 1990; Layard et al. 1991) have challenged Calmfors and Drifill's conclusions and proposed a negative linear relationship. Their argument is that the favourable performance effects of increasing centralization that arise from taking the macroeconomic results of any agreement on wages into consideration are stronger than the adverse effects from imperfect product market competition. In addition, Soskice (1990) concentrates on coordination instead of centralization. He argues that it is not the locus of the formal wage bargaining that is relevant but the degree of consensus between the agents in the collective bargaining process. In this way, co-ordination and centralization may be seen as two different paths to achieving the same goal.

The relationship between the degree of centralization or co-ordination in the wage-bargaining process and the unemployment level in a country holds even more strongly if we look at youth unemployment rates as opposed to general unemployment rates. School leavers are newcomers on the labour market and are therefore-by definition-considered to be outsiders. As they still have to find a position in the employment system, they are more vulnerable to changes in labour market conditions. This is easily shown by the fact that youth unemployment rates have steeper fluctuations over time than general unemployment rates. Therefore, our first hypothesis is that the more centralized/ co-ordinated the wage-bargaining structure in a country is, the more likely it is that in that country young people will be integrated into the labour market (hypothesis 1).

Irrespective of the degree of centralization/co-ordination in the wagebargaining structure, it is assumed that the degree to which workers' wages are determined by collective bargaining or the degree to which workers are unionized in a country is important. In practice, most members of trade unions are already working. Therefore, unions represent insiders rather than outsiders and union power can be characterized as insider power. We expect the power of unions to play an important role in the integration process of young people into the labour market: the more power unions have in a country, the less likely it is that within this country young people are integrated into the labour market (hypothesis 2). 
Apart from wage-bargaining, insiders also negotiate on employment protection. Employment protection refers to regulations concerning both hiring and firing and is intended to reduce the economic uncertainty of workers by enhancing job security (OECD 1999a: chapter 2). In general, insiders try to increase their job security by firmly establishing a number of employment conditions (such as period of notice, severance pay, seniority) in the legislation and/or in collective labour agreements. Here, seniority is a major criterion. Usually, this principle prohibits settled employees from being fired and young people, who are the last employees to enter the firm, will be the first to be fired if the firm needs to do so. This is called the last in, first out (LIFO) principle (see e.g. Oswald 1987). For outsiders, this means that employment protection will tend to trap them in long-term unemployment or-when personnel adjustment is done according to the LIFO principle-in an unstable position between unemployment and temporary jobs. This is especially true of school leavers. From this point of view, employment protection legislation undermines the chances of establishing a stable LM position for young people. This leads to the hypothesis that the stricter the employment protection legislation is in a country, the less likely it is that young people there will be integrated into the labour market (hypothesis 3).

\section{Vocational specificity and dual system}

Apart from national differences in the regulation of the labour market, crossnational variation with regard to institutional arrangements in education and training systems also affects the integration process of young people into the labour market. First of all, countries differ in the extent to which there is an institutional link between the education and training system, on the one hand, and the employment system on the other (Maurice et al. 1982; Hannan et al. 1997; Müller and Shavit 1998). Basically, this debate refers to the extent to which education systems differentiate between academic and vocational education. Some countries offer mainly general education. In such countries, education is weakly related to the workplace and vocational training is primarily obtained on the job. In other countries, occupation-specific skills are taught in the education and training system. Here, the link between the education/ training system and the employment system is strong. The way this close link between the education/training system and the employment system is institutionalized may differ. In some cases, the teaching of vocational skills is shared between vocational schools and the workplace, such as in the apprenticeship systems in Germany and other countries (the 'dual system'). In other cases, however, the provision of vocational skills is primarily school based.

In vocational programmes that are mainly occupation specific-irrespective of how these programmes are institutionalized in the education system-school 
leavers have specific skills that prepare them for particular jobs. For employers these school leavers are very attractive since the curricula of the vocational programmes already supply them the skills required for the job and this reduces the training costs for employers. Consequently, in countries that provide a differentiated system of vocational education, we can expect the association between education and labour market outcomes to be closer and, subsequently, young people to be more easily integrated into the labour market than in countries that primarily offer general education. This leads to the following hypothesis: the more vocationally specific the education system is in a country, the more likely it is that young people in that country will be integrated into the labour market (hypothesis 4).

The vocational specificity of the education system directly affects the expected training costs of school leavers. The way vocational education is organized (in full-time vocational tracks or in apprenticeships) may have additional effects on the integration process as well. One of the underlying factors of the 'success' of the dual system is that it decreases the selection and allocation costs for employers: the dual system offers them a possibility of screening potential employees during their training and to mould their skills to the firm's specific needs. From the point of view of the school leavers, being an apprentice offers them an advantage in the allocation process. They have 'a foot in the door' and are thus more successful in acquiring a permanent position within the firm than school leavers from full-time vocational tracks. We may therefore expect that, in a country with a dual system, young people are more likely to be integrated into the labour market than in a country where education is organized in full-time schools (hypothesis 5).

\section{Standardization and stratification}

In different countries, the school-to-work transition also varies according to the standardization of educational provisions and the stratification of educational opportunities in the education system (Allmendinger 1989; Müller and Shavit 1998). Standardization concerns the degree to which the quality of education meets the same standards nationwide-for example with regard to teacher training, school budgets, curricula, and uniformity of examination/ certification terms. Stratification has to do with the extent and form of tracking at the secondary educational level (see Müller and Shavit 1998: 50). In highly stratified education systems, pupils are divided into separate tracks very early in their educational careers. Furthermore, in these systems it is difficult to switch between tracks, since the tracks are too diverse. On the other hand, in countries characterized by a low degree of stratification, the 
diversity between different tracks is limited, which facilitates mobility between tracks.

It is assumed that the relationship between the educational qualifications and LM outcomes of individuals is closer in countries that have a highly standardized and stratified education system. The reason for this is that high standardization and stratification make screening easier for employers. High standardization makes the qualities of school leavers simple to interpret and compare. High stratification leads to detailed differentiation in the outflow of education. Once again, this makes screening easier for employers, because in that situation employers know exactly what kind of school leaver they need to accept for the specific vacancy they have. In the absence of high standardization and high stratification, it will be more difficult for employers to screen the best qualified individuals for the vacancies they have. Therefore, we can expect a high degree of standardization and stratification of the education system to facilitate the integration of young people into the labour market. Since in most European countries the education/training systems are highly standardized-in contrast with, for instance, the United States and maybe the United Kingdom in Europe (Müller and Shavit 1998; Hannan et al. 1999a)-we restrict the next hypothesis to the stratification of the education system: the more stratified the education system is in a country, the more likely it is that in that country young people will be integrated into the labour market (hypothesis 6).

\section{Selectivity}

Finally, the selectivity of the education system affects transition processes from school to work. In this chapter, selectivity refers to the degree of expansion of tertiary education. In general, educational participation has grown everywhere in Europe in recent decades, but it has done so from different starting points, in different ways, and with different results (see Müller and Wolbers, Chapter 2 of this volume). Educational growth has been motivated by various considerations. First of all, the increase in educational participation has been advocated on the ideological plane in order to reduce the unequal distribution of educational attainment between different social groups (Shavit and Blossfeld 1993). Second, due to rapid technological changes, more and more occupations on the labour market require higher skill levels (Denison 1962). Third, rapid educational expansion has been an answer to recent social problems, such as youth unemployment, that keep young people out of the labour force-and in the education system-as long as possible (Hannan and Werquin 2001).

In order to enhance educational expansion, institutional reforms in the education system have been implemented almost everywhere. It is assumed that 
existing national traditions in the establishment of educational institutions and the provision of education has affected the course of educational reforms and, subsequently, the degree of educational expansion (see Müller and Wolbers, Chapter 2 of this volume). In particular, the (non-)existence of an established tradition of vocational education has determined the course of reforms. Especially in countries that have no tradition of vocational orientation in secondary education, the need and pressure for an extensive system of tertiary education is large and for these countries one should therefore assume strong growth in educational participation at the tertiary level.

Excessive expansion of tertiary education has detrimental consequences for LM outcomes (Boudon 1974). At the individual level, it forces young people to obtain higher educational qualifications if they want to stay in a favourable position in the job queue (Thurow 1975). At the societal level, high enrolment rates in tertiary education may lead to credential inflation. That is, if there are more highly educated school leavers than the labour market can absorb, the LM value of credentials will decline (Brauns et al. 1997; Wolbers et al. 2001; see also Gangl, Chapter 9 of this volume). In this situation, a number of highly educated individuals have to accept jobs for which the required level of education is lower than the actual level attained ('overeducation'). In addition, the oversupply of highly educated school leavers may lead to a process of bumping down or crowding out, as these higher educated school leavers start competing with the lower educated (Borghans and de Grip 2000). Therefore, we can expect a non-selective education system, characterized by a large growth of educational participation at the tertiary level, to hinder the integration of young people into the labour market. Or, to put it the other way around: the more selective the education system is in a country, the more likely it is that in that country young people will be integrated into the labour market (hypothesis 7). One should bear in mind, however, that this hypothesis refers to the aggregate effects of the expansion of tertiary education. At the individual level, of course, qualifications from tertiary level education improve the chances of integration.

\subsection{Data, variables, and method}

\section{Definition of school leavers}

In this chapter, the European Union Labour Force Survey (EULFS) data set for the period 1992-7 is used as an indicator of the integration of young people into the labour market. Due to their recent accession to the European Union, we only have information for Austria, Finland, and Sweden from the last three years (i.e. since 1995). 
To describe the transition from school to work, we have to define school leavers. Since the EULFS data set is a cross-sectional data set describing current LM participation, individual trajectories into the labour market are not captured by the data and school leavers cannot be directly identified. In this chapter we therefore adopt an indirect approach to identify school leavers. We distinguish two types of school leavers: recent and less recent school leavers. This distinction is made because the two types of school leavers are at different stages of the transition process, which surely has consequences for the extent to which the groups are integrated into the labour market.

In the EULFS data set, information is available about the current employment status of the respondents and their employment status one year previously. As a first step, one could argue that recent school leavers are those who were still in initial education or training one year previously and at present are in the labour force. A drawback to this approach, however, is that a substantial group of young people combine schooling and gainful employment (see Wolbers, Chapter 5 of this volume). The EULFS data set is based on regular $\Pi$ LO conventions and definitions about the labour force ( $L O$ 1990b). This implies that individuals who are currently both in employment and in initial education or training (i.e. working students or young people participating in an apprenticeship programme) are counted as employed, whereas their main activity is actually that of a student. Therefore, a small modification to the ILO definition is applied in this chapter. All people who are employed but who are in initial education or training at the same time are excluded from the labour force. A recent school leaver, therefore, is defined as someone who was in initial education or training one year before the survey and who at the time of the survey is in the labour force and no longer a student. One should bear in mind, however, that it does not necessarily follow that the respondents in question will have permanently left initial education. It may well be that young people leave the education system temporarily and return later. Consequently, some individuals that are considered here as recent school leavers are not school leavers in the strict sense.

To define the group of less recent school leavers, we use the typical graduation age of students, which is the average age of the group of recent school leavers during the survey. We compute this average graduation age for each educational level and for each country. Taking this graduation age into account, a less recent school leaver is defined as someone who is in the labour force at present and no longer a student and who, given his or her educational level and country, is between one and five years older than the typical graduation age of a school leaver with the same educational level and living in the same country. This definition implies that throughout the various countries we are comparing individuals who have (potentially) equal LM experience. This is of crucial importance for comparing national differences in the integration of young people into the labour market. 


\section{Other independent variables at the individual level}

The differentiation of the various kinds of qualification levels and the identification of similar levels across countries constitutes a difficult task because of the different structures in the education systems. In particular, it is problematic to establish equivalences among different tertiary level certificates in different countries. Some countries classify certain programmes as secondary level education, whereas others regard them as tertiary level education. For the current analysis, therefore, we use a broad, rather than a narrow, definition of educational levels. We distinguish three levels of education based on the International Standard Classification of Education (ISCED) (UNESCO 1975), namely the lower level (ISCED 0-2), the intermediate level (ISCED 3), and the upper level (ISCED 5-7).

Gender differences with respect to the integration process are investigated by distinguishing men and women in the analysis.

\section{Independent variables at the contextual level}

To measure the level of centralization and co-ordination in the wage-bargaining structure of a given country, we have established three distinct categories. Table 7.1 shows that Austria and Germany are defined as countries with a centralized/co-ordinated wage-bargaining system. Ireland and the United Kingdom are classified as decentralized/uncoordinated. All other countries within the European Union represent systems in which wage bargaining takes place at the intermediate level. The power of trade unions is operationalized as the proportion of workers who are members of a trade union. Trade union membership within the European Union is most common in the Scandinavian countries. In France and Spain, on the other hand, union density is rather low. Employment protection, measured by the overall strictness of employment protection legislation, is highest by far in the southern European countries (see also Iannelli and Soro-Bonmatí, Chapter 8 of this volume). In Ireland and the United Kingdom, however, the existing labour force has relatively little protection against dismissals and other forms of job insecurity.

In Table 7.2, the countries are classified by the institutional characteristics of their education and training systems. The vocational specificity of the education and training system is measured by the participation rate of upper secondary level students in vocational training. Especially in (the countries around) Germany and the Scandinavian countries, the percentage of upper secondary level students enrolled in vocational education is high, whereas in southern Europe, the United Kingdom, and Ireland, the general track is predominant within upper secondary education. In addition, we make a distinction between countries that have institutionalized vocational training by means of a combination of working and learning ('dual system') and countries where vocational training is mainly school based. Countries with an extensive dual system are 
Table 7.1. National institutional contexts with regard to employment systems

\begin{tabular}{lccc}
\hline Country & $\begin{array}{c}\text { Wage-bargaining } \\
\text { structure }\end{array}$ & Union density (\%) & $\begin{array}{c}\text { Employment } \\
\text { protection }^{\mathbf{c}}\end{array}$ \\
\hline Austria & 3 & 42 & 2.2 \\
Belgium & 2 & 54 & 2.6 \\
Germany & 3 & 29 & 2.9 \\
Denmark & 2 & 76 & 1.7 \\
Spain & 2 & 19 & 3.4 \\
Finland & 2 & 81 & 2.1 \\
France & 2 & 9 & 2.9 \\
Greece & 2 & 24 & 3.6 \\
Ireland & 1 & 49 & 0.9 \\
Italy & 2 & 39 & 3.7 \\
Luxembourg & 2 & 43 & 2.5 \\
The Netherlands & 2 & 26 & 2.4 \\
Portugal & 2 & 32 & 3.9 \\
Sweden & 2 & 91 & 2.4 \\
United Kingdom & 1 & 34 & 0.5 \\
\hline
\end{tabular}

a Wage-bargaining structure is a combined indicator that measures the degree of centralization and co-ordination of the wage-bargaining system in a country. The values are based on data for 1994, as reported in OECD Employment Outlook of 1997 (OECD 1997b: table 3.3). A '3' indicates a centralized/co-ordinated wage-bargaining structure, a ' 2 ' is assigned to countries with an intermediate wage-bargaining structure, and a ' 1 ' refers to countries where wage bargaining is decentralized/uncoordinated. The value for Ireland is based on Nickell and Layard (1997). Greece and Luxembourg are, for lack of data, assigned to the EU average.

b Trade union density is based on the rates of 1994, as published in OECD Employment Outlook of 1997 (OECD 1997b: table 3.3). The figures for Greece and Ireland stem from Ebbinghaus and Visser (1999) and are the rates of 1995. The union density rate for Luxembourg is the unweighted average of the other countries.

${ }^{c}$ Employment protection is measured by the overall strictness of employment protection legislation (EPL) in a country, as published in OECD Employment Outlook of 1999 (OECD 1999a: table 2.5). This summary indicator refers to protection with regard to both regular and temporary employment. The figures used here are the average of the scores for the late $1980 \mathrm{~s}$ and late 1990s. The figure for Luxembourg is computed as the unweighted average of all other countries, since there are no data available for this country.

Austria, Germany, Denmark, Luxembourg, and the Netherlands. There is a relationship between vocational specificity and the stratification of the education system. In this chapter, we define the secondary education systems of Austria, Germany, Luxembourg, and the Netherlands as highly stratified, in the sense that pupils are differentiated into tracks very early in their educational careers (at the end of primary education). The United Kingdom, Ireland, Portugal, and the Scandinavian countries, on the other hand, represent countries with a low degree of stratification in secondary education. The selectivity of the 
Table 7.2. National institutional contexts with regard to education and training systems

\begin{tabular}{lcccc}
\hline Country & $\begin{array}{l}\text { Participation in } \\
\text { vocational training } \\
(\%)^{\mathrm{a}}\end{array}$ & Dual system $^{\mathrm{b}}$ & $\begin{array}{l}\text { Stratification } \\
\text { of secondary } \\
\text { education }^{\mathrm{c}}\end{array}$ & $\begin{array}{c}\text { Tertiary education } \\
\text { qualifactions }(\%)^{\mathrm{d}}\end{array}$ \\
\hline Austria & 76 & 1 & 2 & 8 \\
Belgium & 59 & 0 & 1 & 29 \\
Germany & 80 & 1 & 2 & 21 \\
Denmark & 56 & 1 & 0 & 25 \\
Spain & 41 & 0 & 1 & 24 \\
Finland & 54 & 0 & 0 & 23 \\
France & 54 & 0 & 1 & 18 \\
Greece & 21 & 0 & 1 & 27 \\
Ireland & 15 & 0 & 0 & 23 \\
Italy & 67 & 0 & 1 & 12 \\
Luxembourg & 54 & 1 & 2 & 26 \\
The Netherlands & 70 & 1 & 2 & 23 \\
Portugal & 14 & 0 & 0 & \\
Sweden & 76 & 0 & 0 & \\
United & 58 & 0 & 0 & \\
Kingdom & & & & 23 \\
\hline
\end{tabular}

articipation in vocational training is measured as the percentage of upper secondary students enrolled in public and private vocational education (including apprenticeships). The figures were reported in OECD, Education at a Glance 1995 (OECD 1995a: table P03(B)). The percentages for Greece, Luxembourg, Portugal, and Sweden are based on Figure 2.10 of this volume. The percentage for Ireland is based on a conversation with Philip J. O'Connell from the Economic and Social Research Institute in Dublin.

b A ' 1 ' represents countries with an apprenticeship system in which learning and working are combined ('dual system'). All other countries are assigned to category ' 0 ', which indicates the absence of an extensive dual system.

c Stratification of secondary education is based on table 1.1.a of Müller and Shavit (1998). It is coded as follows: a ' 0 ' represents the prevalence of comprehensive schools, which may or may not practise curricular and/or ability-based tracking. A ' 1 ' represents a prevalence of betweenschool tracking such that those on the academic track usually attend separate schools from those on the lower or vocational track. A ' 2 ' represents an extreme form of stratification with very early differentiation among a multitude of programmes. For Austria, Belgium, Denmark, Spain, Finland, Greece, Luxembourg, and Portugal, all of which are countries that are missing in Müller and Shavit (1998), we took the information on the stratification of secondary education as reported in Hannan et al. (1999a) and OECD (1995a).

"Percentage of the population (25-59 years of age) that has attained any degree in tertiary education (ISCED 5-7) is used as an indicator for the selectivity of the education system. The figures originate from Figure 2.2 of this volume.

education system is operationalized as the percentage of the population that has attained tertiary education. It is assumed that the education system is more selective in countries where the attainment of tertiary education is lower. Table 7.2 shows that Austria, Italy, and Portugal have the lowest proportions 
of individuals with higher education. The highest percentages can be found in Belgium, Sweden, Ireland, Denmark, and Spain.

An important factor affecting youth labour market chances is the nature of general LM conditions. These conditions may differ over time. Some countries may go through a recession, whereas others can be in the middle of an upturn at the same time. To prevent these differences in the general LM situation playing a distorting role in determining the impact of national institutional contexts, the effect of the general LM conditions has to be taken into account. Therefore, we include aggregate unemployment rates as a contextual variable in the analysis. The unemployment rates are based on the unemployed labour force aged between fifteen and fifty-nine years. The cross-national variation in trends over the period $1992-7$ is presented in Figure 7.2. From this figure, we

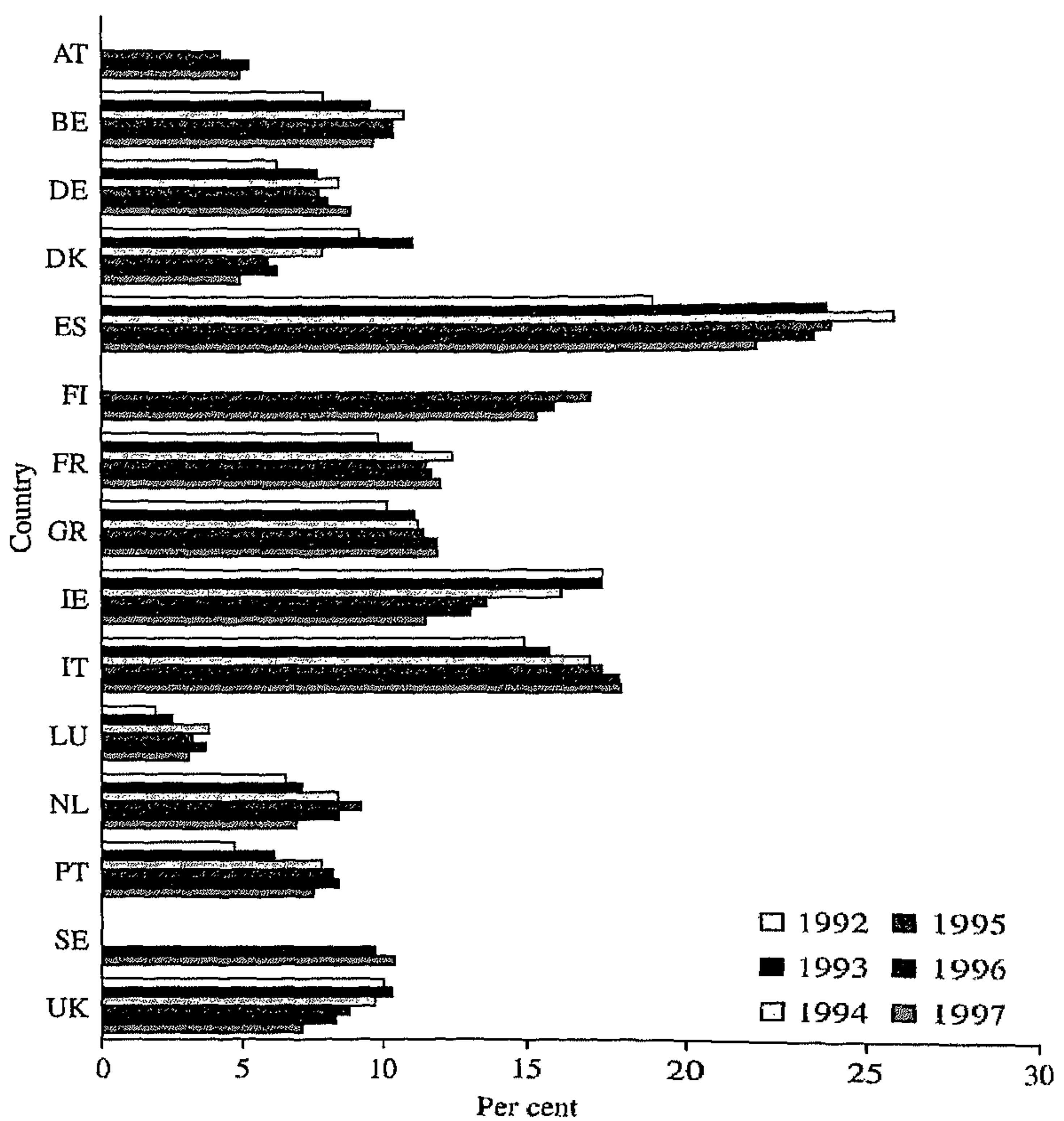

Figure 7.2. Aggregate unemployment rates, by country and period.

Source: Pooled EULFS data 1992-7. 
can observe that countries are indeed at different stages of the business cycle. In countries such as Germany, we find a rather low but increasing level of unemployment. In countries such as Ireland, on the other hand, a clear decrease in the overall unemployment rate can be observed. Other countries show a fluctuating trend over time. In the Netherlands, for instance, we observe a rising percentage of unemployed people for the first years, followed by a decline in the later years.

\section{Dependent variables}

We analyse two important aspects in the (lack of) labour market integration of young people: unemployment and temporary employment. Although these labour market outcomes do not give a full picture of the integration of school leavers into the labour market, they at least represent a good approximation of it. Unfortunately, the availability of adequate dependent variables with regard to youth LM integration in the EULFS data set is rather limited. The results for the total group of school leavers (i.e. the recent and the less recent school leavers) were presented in Figure 7.1. Here we restrict ourselves to the operationalization of the two indicators.

As mentioned above, we use a modified ILO definition to determine the labour force. According to the standard definition, the labour force consists of any individuals who (1) have paid work (even for as little as one hour) or (2) are not working but have a job from which they are absent at the moment or (3) are looking for work and can start working within two weeks. Our deviation from this definition is that all individuals currently participating in initial education or training are excluded from the labour force. The unemployed labour force is made up of individuals who come under condition (3). The permanency of a job is measured by making a distinction between permanent and temporary jobs. A temporary position refers to a job with a work contract of limited duration.

\section{Method of analysis}

The method used for estimating cross-national variation in the integration process is multilevel analysis (see, for instance, Goldstein 1995 or Snijders and Bosker 1999). We distinguish three levels of analysis: the school-leaver level, the period level, and the country level. The hierarchical structure in the data enables us to make an adequate estimate of cross-national variation, since individual variation within countries and period variation within countries are statistically controlled for in the analysis. In total, we estimate six separate models in which only the intercept is allowed to vary randomly ('random intercept model'). We thus assume that the effects of all other parameters are 
constant over time and between countries. In the baseline model, we start with a description of 'gross' variation between countries. In principle, this gross variation is the same as the differences observed in LM outcomes between countries shown in Figure 7.1. In the subsequent models, we try to explain these gross differences between countries by taking into account the effects of the composition of the population of school leavers (with respect to level of education, gender, and type of school leaver), the general LM situation, and institutional contexts, with regard to both the employment system and the education/ training system. This gives us an insight into 'net' variation between countries.

\subsection{Results}

\section{Likelihood of unemployment}

Table 7.3 presents the results of multilevel analysis regarding the likelihood of unemployment. Model 0 gives an estimation of the systematic variation between countries ('between-country variation') and the variation within countries between different periods ("within-country between-period variation'). Due to the dichotomous nature of the dependent variable, the variation at the individual level cannot be estimated and is therefore fixed at the value $1 .{ }^{1}$ Consequently, we are not able to estimate the extent to which this variation at the individual level can be explained by the predictors in the different models. Nor can the variation between countries or between periods be expressed as a proportion of the total variance. The different variance components are displayed at the bottom of the table. The variance component of model 0 shows the gross variation between countries. The analysis shows that there are significant differences between countries in the odds of becoming unemployed (between-country variation is 0.546 ). There is also a significant variation within countries between different periods $(0.021)$ but these differences are relatively small compared to the systematic variation between countries.

The introduction of individual characteristics in model 1 shows that the odds of being unemployed are significantly influenced by the personal background of school leavers. For recent school leavers, the likelihood of being unemployed as opposed to employed is around twice as large (2.305) as for less recent school leavers. Those who have left education at the ISCED 0-2 level also have unfavourable opportunities on the labour market. Their

1 Furthermore, in multilevel logistic regression analysis the deviance values produced are such crude approximations that they cannot be used in reliable deviance tests (see Goldstein 1995: 103; Snijders and Bosker 1999: 220). For that reason, chi-squared tests or other related fit-statistics are not presented in the current analysis. 
Table 7.3. Results of logistic three-level analysis of being unemployed (in terms of odds ratios)

\begin{tabular}{|c|c|c|c|c|c|c|}
\hline Model & 0 & 1 & 2 & 3 & 4 & 5 \\
\hline \multicolumn{7}{|l|}{ Type of school leaver } \\
\hline Recent & & $2.305^{\mathrm{a}}$ & $2.469^{\mathrm{a}}$ & $2.479^{\mathrm{a}}$ & $2.487^{\mathrm{a}}$ & $2.487^{\mathrm{a}}$ \\
\hline Less recent & & Ref. & Ref. & Ref. & Ref. & Ref. \\
\hline \multicolumn{7}{|l|}{ Level of education } \\
\hline ISCED 0-2 & & $2.413^{\mathrm{a}}$ & $2.555^{\mathrm{a}}$ & $2.550^{\mathrm{a}}$ & $2.563^{\mathrm{a}}$ & $2.552^{\mathrm{a}}$ \\
\hline ISCED 3 & & $1.618^{\mathrm{a}}$ & $1.660^{\mathrm{a}}$ & $1.655^{\mathrm{a}}$ & $1.660^{\mathrm{a}}$ & $1.657^{\mathrm{a}}$ \\
\hline ISCED 5-7 & & Ref. & Ref. & Ref. & Ref. & Ref. \\
\hline \multicolumn{7}{|l|}{ Sex } \\
\hline Male & & Ref. & Ref. & Ref. & Ref. & Ref. \\
\hline Female & & $1.169^{\mathrm{a}}$ & $1.182^{\mathrm{a}}$ & $1.183^{\mathrm{a}}$ & $1.183^{\mathrm{a}}$ & $0.183^{\mathrm{a}}$ \\
\hline Aggregate unemployment rate (\%) & & & $1.129^{\mathrm{a}}$ & $1.127^{\mathrm{a}}$ & $1.126^{\mathrm{a}}$ & $1.124^{\mathrm{a}}$ \\
\hline Wage-bargaining structure & & & & 0.795 & & \\
\hline Union density $(\%)$ & & & & 1.001 & & \\
\hline Employment protection & & & & $1.260^{\mathrm{c}}$ & & 1.137 \\
\hline Participation in vocational training $(\%)$ & & & & & 1.003 & \\
\hline Dual system & & & & & $0.591^{\mathrm{b}}$ & $0.679^{\mathfrak{c}}$ \\
\hline Stratification of secondary education & & & & & 0.999 & \\
\hline Tertiary education qualifications (\%) & & & & & 0.992 & \\
\hline \multicolumn{7}{|l|}{ Variance components } \\
\hline School leaver level $(N=129,483)$ & 1 & 1 & 1 & 1 & 1 & 1 \\
\hline Period level $(N=80)$ & $0.021^{\mathrm{a}}$ & $0.029^{\mathfrak{a}}$ & $0.004^{b}$ & $0.005^{\mathrm{a}}$ & $0.004^{\mathrm{b}}$ & $0.004^{b}$ \\
\hline Country level $(N=15)$ & $0.546^{\mathrm{a}}$ & $0.524^{\mathrm{a}}$ & $0.165^{\mathrm{a}}$ & $0.150^{\mathrm{a}}$ & $0.184^{\mathrm{a}}$ & $0.121^{\mathrm{a}}$ \\
\hline
\end{tabular}

${ }^{a} p<0.01$.

$p<0.05$

${ }^{c} p<0.10$.

Ref. $=$ reference category.

Note: Two-tailed tests; one-tailed tests for country effects.

Source: Pooled EULFS data 1992-7.

unemployment probability is 2.413 times higher than for individuals who left education at the tertiary level (ISCED 5-7). Those who left education at the intermediate level (ISCED 3) hold an intermediate position. Furthermore, model 1 shows that women have a higher probability of being unemployed than men. The implied odds ratio is 1.169 . Despite these effects, none of the individual characteristics seems to have an impact on the differences in unemployment rates between time periods or between countries. This is shown by the fact that the variance components at the country and period level in model 1 have hardly changed compared to those in the baseline model. This indicates that the differences between countries and within countries between years are related to other factors than the composition effects of the population of school leavers in the different countries. 
Not surprisingly, the most important of these other factors is the general LM situation. After controlling for the aggregate unemployment rate in model 2 , the residual variance component decreases at the country level from 0.524 to 0.165 and at the period level from 0.029 to 0.004 . In other words, around two-thirds of the systematic differences between countries and almost 90 per cent of the variation within countries between periods can be statistically explained by differences in the general LM situation. This means that the unemployment risk of school leavers is primarily determined by general employment conditions, which also affect the rest of the labour force. Still, there are significant differences, especially at the national level.

The next models show that part of these remaining differences between countries can be explained by national institutional contexts. ${ }^{2}$ In model 3 , the effect of LM regulation is shown. In countries characterized by strong employment protection for the existing labour force, school leavers have a higher probability of being unemployed than in countries that are more open to newcomers. This corroborates hypothesis 3 . There is no significant effect from the wage-bargaining structure, although the sign is in the expected direction. Furthermore, union density does not seem to have any effect at all on the likelihood of school leavers being unemployed.

In model 4, the characteristics of the education and training system are included. The results are fairly straightforward. In countries with a firmly established dual system, the odds of being unemployed are 0.591 times smaller for school leavers than the corresponding odds in countries where the dual system is of little importance. This clearly supports hypothesis 5. However, note that the effect of the dual system is not in itself related to the vocational orientation of the education system. As dual systems are by definition strongly vocation oriented, it is important to distinguish between these two characteristics. The positive effect of the dual system on the integration of young people stems from the strong allocation function it has, that is, the institutionalized pathway it provides for young people to enter the labour market. The effect does not seem to be related so closely to the more strongly vocational orientation of countries with a dual system, since the effect of the proportion of upper secondary education students enrolled in vocational training is not significant. This means that hypothesis 4 is refuted.

${ }^{2}$ Due to the small number of degrees of freedom at the national level $(N=15)$, a high level of multicollinearity can occur between the explanatory variables. Indeed, some national characteristics are relatively strongly (but not extremely strongly) correlated (see Appendix Table 7A.1). For this reason, we have decided to estimate different model specifications. Appendix Table 7A.2 reports on estimates obtained from regressions in which (ceteris paribus) only one national characteristic is included at the same time. Since the results of these regressions show similar significant effects for national characteristics as reported in Tables 7.3 and 7.4, we can be fairly confident of the reality of such effects. 
Model 5 integrates models 3 and 4 by taking up only the significant effects of the two models. We can see that both groups of institutional factors have their own independent effect on the unemployment risk of school leavers, although the effect of employment protection loses significance. Taken together, the two variables explain one-third of the residual variance in model 2 . In other words, after taking general LM conditions into account, some of the remaining national differences can be attributed to differences in institutional arrangements, namely employment protection legislation and the existence of a dual system. Both the differences between countries and the differences within countries between periods are largely (about 80 per cent) explained by the variables in the model.

The effects are clearest when we look at so-called 'posterior means'. A posterior mean reflects the performance of a country as a deviation from the overall performance within the European Union, after controlling for other variables. Figure 7.3 displays these posterior means for three different models. The posterior means of model 0 are similar to the percentages of the upper panel of Figure 7.1. However, these percentages are now expressed as predicted deviations from the overall percentage within the European Union. The pattern of percentage differences between the countries in model 0 is exactly in line with the description of the differences presented earlier. We see high proportions in Italy, Spain, and Greece and low proportions in Luxembourg, Austria, the Netherlands, and Germany. The percentage differences between the countries in the other two models show what happens when certain variables are controlled for.

It can immediately be seen from Figure 7.3 that the deviations between the countries are almost fully explained by the variables in the model. The extremely high unemployment rate among school leavers in Spain (see model 0),

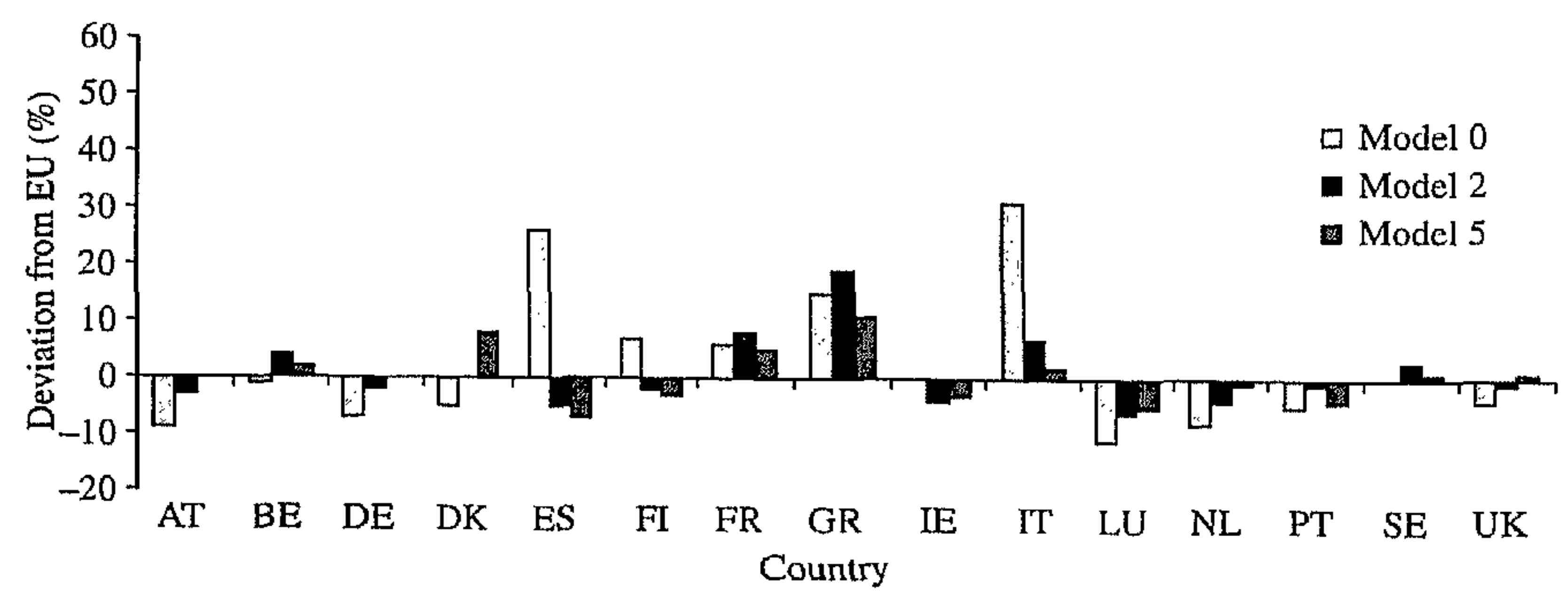

Figure 7.3. Cross-country performance with regard to being unemployed.

Source: Pooled EULFS data 1992-7. 
for example, is fully explained by the aggregate unemployment level in that country. Once we control for that effect, unemployment among school leavers in Spain is in fact lower than the overall unemployment level of school leavers within the European Union (see model 2). A similar result is found for Italy. The high unemployment rate for school leavers in that country can be fully explained by an unfavourable general LM situation and by the national institutional context (high employment protection and the absence of a dual system). Greece seems to be an exception. The unemployment rate among school leavers is higher than would be expected, given the aggregate unemployment rate. The high unemployment rate among young people in that country can only partly be explained by the institutional factors in the model, given the fact that in model 5 Greece still shows a relatively large percentage difference.

Conversely, the low unemployment rates among school leavers in countries such as Austria, Germany, Luxembourg, the Netherlands, and Denmark seem to be caused by favourable general LM conditions and the existence of a dual system. Denmark also profits from relatively low restrictions from employment protection legislation.

\section{Likelihood of having a temporary job}

Table 7.4 presents the results of multilevel analysis with regard to the likelihood of having a temporary job. Model 0 again describes the variance between countries and within countries between years. The variation between countries seems larger than in the previous analysis: 0.943 as against 0.546 with respect to the odds of being unemployed.

In model 1 the individual characteristics are introduced into the analysis. The largest effect stems from the type of school leaver. For recent school leavers, the odds of having a temporary job are more than three times higher than for less recent school leavers. Furthermore, low-educated school leavers (ISCED 0-2) are more often in temporary positions than their highly educated fellows (ISCED 5-7). The implied odds ratio is 1.428. There is no effect of gender on the odds of having a temporary job. Both females and males run the same risk of temporary work. None of these individual characteristics has an effect on the overall variation between countries.

Variation between countries with regard to the likelihood of school leavers having a temporary job is strongly affected by differences in the general LM situation (see model 2). For each percentage increase in a country's unemployment rate, the odds for school leavers having a temporary job rise with 1.048 points. Almost half of the original cross-national variation can be explained by differences in the general LM situation of the different countries. Interestingly, the within-country variation does not appear to be affected by the aggregate unemployment level (0.015 as compared to 0.013). Apparently, 
$R$. van der Velden and $M$. Wolbers

Table 7.4. Results of logistic three-level analysis of having a temporary job (in terms of odds ratios)

\begin{tabular}{|c|c|c|c|c|c|c|}
\hline Model & 0 & 1 & 2 & 3 & 4 & 5 \\
\hline \multicolumn{7}{|l|}{ Type of school leaver } \\
\hline Recent & & $3.142^{\mathrm{a}}$ & $3.384^{\mathrm{a}}$ & $3.494^{\mathrm{a}}$ & $3.367^{\mathrm{a}}$ & $3.561^{\mathrm{a}}$ \\
\hline Less recent & & Ref. & Ref. & Ref. & Ref. & Ref. \\
\hline \multicolumn{7}{|l|}{ Level of education } \\
\hline ISCED 0-2 & & $1.428^{\mathrm{a}}$ & $1.474^{\mathrm{a}}$ & $1.489^{\mathrm{a}}$ & $1.480^{\mathrm{a}}$ & $1.504^{\mathrm{a}}$ \\
\hline ISCED 3 & & 1.027 & $1.037^{\mathrm{c}}$ & $1.043^{\mathrm{c}}$ & $1.039^{\mathrm{c}}$ & $1.045^{\mathrm{b}}$ \\
\hline ISCED 5-7 & & Ref. & Ref. & Ref. & Ref. & Ref. \\
\hline \multicolumn{7}{|l|}{ Sex } \\
\hline Male & & Ref. & Ref. & Ref. & Ref. & Ref. \\
\hline Female & & 1.000 & 0.999 & 1.000 & 0.999 & 1.000 \\
\hline $\begin{array}{l}\text { Aggregate unemployment } \\
\text { rate }(\%)\end{array}$ & & & $1.048^{\mathrm{a}}$ & $1.047^{\mathrm{a}}$ & $1.048^{\mathrm{a}}$ & $1.048^{\mathrm{a}}$ \\
\hline Wage-bargaining structure & & & & 0.730 & & \\
\hline Union density (\%) & & & & 1.006 & & \\
\hline Employment protection & & & & $1.613^{\mathrm{b}}$ & & $1.317^{\mathrm{c}}$ \\
\hline $\begin{array}{l}\text { Participation in vocational } \\
\text { training (\%) }\end{array}$ & & & & & 1.005 & \\
\hline Dual system & & & & & $0.444^{\mathrm{c}}$ & $0.539^{\mathrm{c}}$ \\
\hline $\begin{array}{l}\text { Stratification of secondary } \\
\text { education }\end{array}$ & & & & & 0.972 & \\
\hline $\begin{array}{l}\text { Tertiary education } \\
\text { qualifications (\%) }\end{array}$ & & & & & 1.018 & \\
\hline \multicolumn{7}{|l|}{ Variance components } \\
\hline $\begin{array}{l}\text { School-leaver level } \\
(N=83,357)\end{array}$ & 1 & 1 & 1 & 1 & 1 & 1 \\
\hline Period level $(N=79)$ & $0.013^{\mathrm{a}}$ & $0.013^{\mathrm{a}}$ & $0.015^{\mathrm{a}}$ & $0.018^{\mathrm{a}}$ & $0.016^{\mathrm{a}}$ & $0.016^{\mathrm{a}}$ \\
\hline Country level $(N=15)$ & $0.943^{\mathrm{a}}$ & $0.936^{\mathrm{a}}$ & $0.526^{\mathrm{a}}$ & $0.498^{\mathrm{a}}$ & $0.569^{a}$ & $0.426^{\mathrm{a}}$ \\
\hline
\end{tabular}

a $p<0.01$.

${ }^{b} p<0.05$.

e $p<0.10$

Ref. $=$ reference category.

Note: Two-tailed tests; one-tailed tests for country effects.

Source: Pooled EULFS data 1992-7.

variation over time is caused by other factors than the general LM situation in a particular year.

In model 3 the institutional characteristics of the employment system are introduced into the analysis. As stated in hypothesis 3, in countries characterized by strict employment protection legislation, the likelihood of having a 
temporary job is higher than in countries with less strict employment protection legislation. The effects of the two other institutional characteristics of the employment system (wage-bargaining structure and union density) also point in the expected direction but are not significant. In total, the institutional factors operative in the employment system cause a drop in cross-national variation from 0.526 in model 2 to 0.498 in model 3 . This is a reduction of some 5 per cent.

Model 4 introduces factors related to different institutional contexts of the education and training system. From this model we see that in countries with a marked dual system the likelihood of school leavers having a temporary job is 0.444 times smaller than in countries that do not have an extensive dual system. Again, this supports hypothesis 5. The other characteristics of the education/training system do not have any significant effect.

The last model (model 5) again includes the significant effects of employment protection and the existence of a dual system. These variables explain about half of the original between-country variation. This means that there are still significant differences left unexplained. Figure 7.4 shows this for each country separately. In the figure, one can clearly see the huge differences in gross performance between countries with regard to the proportion of school leavers with a temporary job. Spain has a very high score-indicating a high proportion of temporary jobs-Luxembourg, on the other hand, a very low one. The figure also shows that the disadvantageous position of Spain can partly be ascribed to the bad general LM circumstances in this country, its high degree of employment protection, and the absence of a dual system. However, these factors do not explain the relatively high score of Finland or the relatively low score of Luxembourg. It seems that for some countries

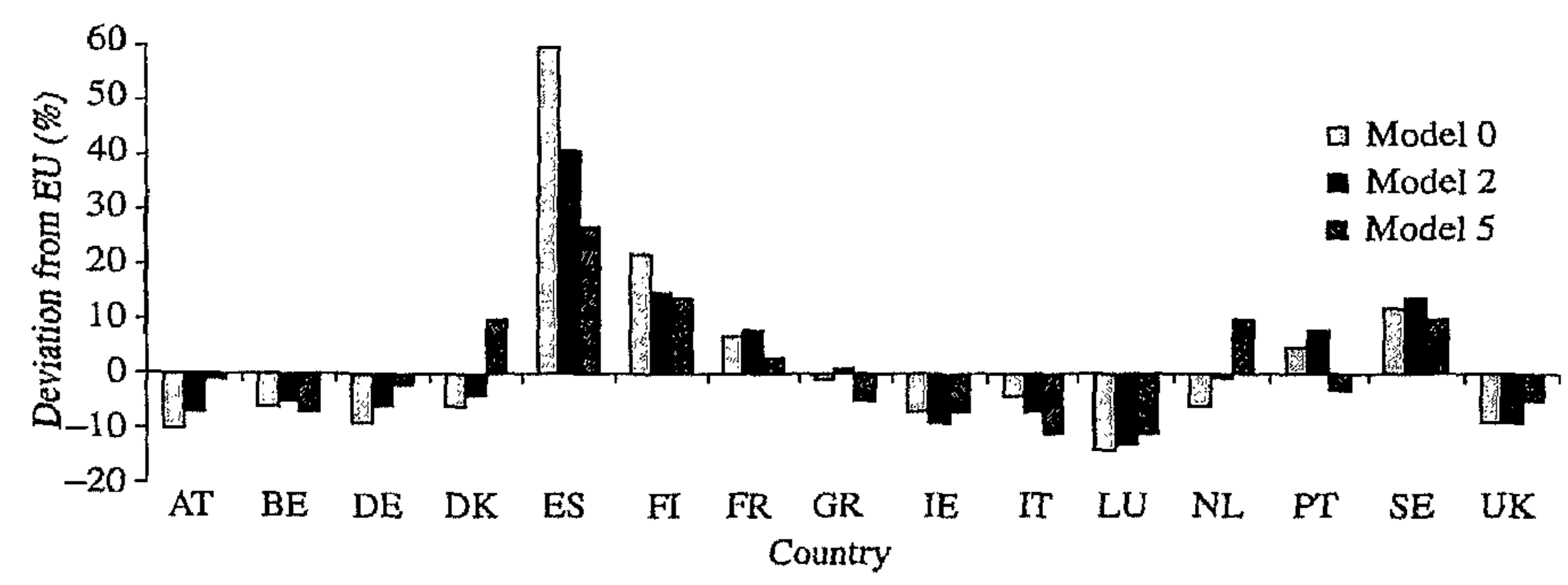

Figure 7.4. Cross-country performance with regard to having a temporary job. Source: Pooled EULFS data 1992-7. 
(for example Austria, Germany, and Portugal), the model does a good job of explaining the country's position, whereas for other countries (for instance Belgium, Finland, Ireland, and Luxembourg) the model does not provide a very good explanation for the proportion of school leavers with a temporary job.

\subsection{Conclusion}

In this chapter we have investigated the extent to which national institutional arrangements for both the education/training system and the employment system affect the integration of young people into the labour market within the European Union. The aim was to determine differences in the integration process between countries and to relate this variation to differences in national institutional contexts. For this purpose, data from the European Union Labour Force Surveys (EULFS) for the period 1992-7 were drawn upon. They provide information about two important aspects in the (lack of) LM integration of young people: unemployment and temporary employment. For an adequate estimate of the systematic variation between countries, we applied multilevel analysis to the data. In this analysis, we statistically controlled for variation within countries between individuals and for variation within countries between periods.

The findings with regard to unemployment show that there are substantial differences between countries. The highest levels of unemployment among school leavers are found in Italy, Spain, and Greece, whereas the lowest unemployment rates are observed in Luxembourg, Austria, the Netherlands, Germany, and Denmark. This cross-national variation in unemployment among school leavers is almost fully explained by differences in the general LM situation, varying institutional contexts with respect to employment protection, and the presence of a dual system. According to our model, for example, the extremely high unemployment rate among school leavers in Spain can be attributed entirely to the high general level of unemployment in this country. If one takes that effect into account, the unemployment rate among school leavers in Spain is in fact lower than the overall level of unemployment among school leavers within the European Union. The same applies to Italy. The high unemployment rate for school leavers in that country can mainly be explained by an unfavourable general LM situation. Furthermore, high employment protection for the existing labour force and the absence of a dual system hinder Italian school leavers in their attempts to find a job. Greece seems to be an 
exception. The high level of unemployment among school leavers there cannot be explained by the general unemployment level in that country, nor by the institutional factors measured in this chapter. On the other hand, the low unemployment rates among school leavers in Germany, Denmark, Austria, Luxembourg, and the Netherlands seem to be caused by the existence of a marked dual system. This effect is clearly present, even after taking the favourable general LM situation in these countries into account. Danish school leavers also profit from the relatively low degree of stringency in employment protection legislation.

The analysis of temporary employment displays huge country differences as well. Especially in Spain and, to a lesser extent, in Finland, school leavers often start work on a temporary contract. In Luxembourg and Austria, on the other hand, the proportion of young people working on a temporary basis is very low. About half of the cross-national variation in the percentage of temporary jobs among school leavers can be explained by the effects of the general LM situation in a country, the degree of employment protection for the existing labour force, and the presence of an extensive dual system. This means, for instance, that the high proportion of temporary jobs among school leavers in Spain can largely be ascribed to the bad general LM circumstances in Spain, the high degree of employment protection there, and the absence of an extensive dual system.

Overall, we can conclude from these results that the LM integration of young people within the European Union is indeed systematically structured by national institutional contexts. First of all, LM regulation matters. Employment protection for the existing labour force has an adverse effect on the integration of young people. In countries with a low degree of employment protection, school leavers find a (stable) LM position more easily than in countries with a high degree of employment protection. In other words, in countries where the existing employees in the labour force (insiders) have a protected position, newcomers (outsiders) will find themselves in a disadvantageous position. In our analysis, the insider-outsider dichotomy could only be demonstrated with respect to employment protection legislation. Two other indicators of this dichotomy - the wage-bargaining structure and trade union density-do not have any effect on the integration process. As employment protection legislation is a direct indicator of the protection of insiders, while the other two are merely indirect ones, we nevertheless take this result as a confirmation of the insider-outsider theory.

In addition, it is clear that the presence of an extensive dual system-as a workplace-based vocational training system-improves the transition from school to work in a country. The positive effect of the dual system on the LM integration of young people may have several causes. One explanation points 
to the strong allocation function of the dual system, that is, the institutionalized pathway it provides for young people to enter the labour market. School leavers from the dual system are not outsiders in the same sense as school leavers from school-based vocational tracks. A second explanation is that employers in a dual system have more information about the skills acquired because they are partly responsible for the training. Finally, the effect may be related to the occupation-specific nature of the skills acquired in the dual system. As employers provide part of the training, the acquired skills may be better tailored to firm-specific needs. It still remains to be seen which of these explanations is most dominant. The results seem to indicate that the effect is not related to the stronger vocational orientation of countries with a dual system, since the vocational orientation in itself-measured as the share of upper secondary education students enrolled in vocational training-does not have an effect on the risk of being unemployed or the likelihood of having a temporary job. However, one might argue that this last indicator does not fully capture the occupational specificity of an educational system in the sense of adequate preparation for specific jobs and occupations. While it is clear that a dual system is always occupation specific, this need not be the case for a school-based vocational track.

Critics might argue that the effects of employment protection and dual systems-in terms of statistical significance-are not very impressive. The strongest effects on LM outcomes are, of course, found in individual characteristics: level of education, gender, and type of school leaver. Moreover, a very important factor in shaping the opportunity structure for school leavers is the general LM situation. Nevertheless, even after taking these factors into account, we may note the substantial differences between countries partly related to the role of education/training systems and LM regulation.

Although the analysis presented here is important in showing why some countries do better with respect to the integration of young people into the labour market than others, the picture is complete. A major limitation is the restricted availability of adequate dependent variables in the data set used. In future research, it will be important to look at other aspects of the integration process, like wages, the match between education undergone and jobs obtained (both with respect to the level and the field of study), the possibility of using acquired skills on the workfloor, career prospects, and job mobility. Given the likely importance of these aspects, there is a strong need for comparative data sets that contain this type of information. This will further improve our understanding of how national institutional contexts affect youth labour market integration. This chapter indicates an innovative way of going about such an analysis. 


\section{Appendix}

Table 7A.1. Bivariate correlations between national institutional contexts

\begin{tabular}{|c|c|c|c|c|c|c|c|}
\hline Variable & 1 & 2 & 3 & 4 & 5 & 6 & 7 \\
\hline $\begin{array}{l}\text { 1. Wage-bargaining } \\
\text { structure }\end{array}$ & 1.000 & & & & & & \\
\hline 2. Union density $(\%)$ & -0.074 & 1.000 & & & & & \\
\hline 3. Employment protection & $0.508^{\mathrm{a}}$ & -0.365 & 1.000 & & & & \\
\hline $\begin{array}{l}\text { 4. Participation in } \\
\text { vocational training (\%) }\end{array}$ & $0.555^{\mathrm{b}}$ & 0.181 & -0.031 & 1.000 & & & \\
\hline 5. Dual system & $0.548^{\mathrm{b}}$ & 0.004 & -0.133 & $0.470^{\mathrm{a}}$ & 1.000 & & \\
\hline $\begin{array}{l}\text { 6. Stratification of } \\
\text { secondary education }\end{array}$ & $0.641^{b}$ & $-0.491^{a}$ & 0.314 & $0.458^{a}$ & $0.644^{\mathrm{b}}$ & 1.000 & \\
\hline $\begin{array}{l}\text { 7. Tertiary education } \\
\text { qualifications (\%) }\end{array}$ & -0.430 & 0.262 & $-0.466^{\mathrm{a}}$ & -0.083 & -0.165 & -0.316 & 1.000 \\
\hline
\end{tabular}

a $p<0.10$.

b $p<0.05$.

Note: $N=15$; two-tailed tests.

Source: Pooled EULFS data 1992-7.

Table 7A.2. Single country effects for the dependent variables

\begin{tabular}{lcc}
\hline Dependent variable & Being unemployed & Having a temporary job \\
\hline Wage-bargaining structure & 0.994 & 1.130 \\
Union density (\%) & 0.998 & 0.999 \\
Employment protection & $1.166^{\mathrm{a}}$ & $1.391^{\mathrm{b}}$ \\
Participation in vocational training (\%) & 0.998 & 0.996 \\
Dual system & $0.644^{\mathrm{b}}$ & $0.482^{\mathrm{b}}$ \\
Stratification of secondary education & 0.895 & 0.746 \\
Tertiary education qualifications $(\%)$ & 0.995 & 1.026 \\
\hline
\end{tabular}

a $p<0.10$.

b $p<0.05$.

Note: Controlling for type of school leaver, level of education, sex, and aggregate unemployment rate; two-tailed tests; one-tailed tests for country effects.

Source: Pooled EULFS data 1992-7. 